\title{
Survival after Sexual Violence and Genocide: Trauma and Healing for Yazidi Women in Northern Iraq
}

\author{
Annekathryn Goodman1*, Hannah Bergbower ${ }^{2}$, Violette Perrotte ${ }^{3}$, Arun Chaudhary ${ }^{4}$ \\ ${ }^{1}$ Department of Obstetrics and Gynecology, Strength \& Serenity MGH Initiative to End Gender Based Violence, Massachusetts \\ General Hospital, Harvard Medical School, Boston, MA, USA \\ ${ }^{2}$ Integral Global, Atlanta, GA, USA \\ ${ }^{3}$ Strength \& Serenity MGH Initiative to End Gender Based Violence, Massachusetts General Hospital, Harvard T.H. Chan School \\ of Public Health, Boston, MA, USA \\ ${ }^{4}$ Department of Obstetrics and Gynecology, Strength \& Serenity MGH Initiative to End Gender Based Violence, Massachusetts \\ General Hospital, Boston, MA, USA \\ Email: `agoodman@mgh.harvard.edu, hannah@integralglobal.net, VPERROTTE@mgh.harvard.edu, \\ achaudhary1@mgh.harvard.edu
}

How to cite this paper: Goodman, A., Bergbower, H., Perrotte, V. and Chaudhary, A. (2020) Survival after Sexual Violence and Genocide: Trauma and Healing for Yazidi Women in Northern Iraq. Health, 12, 612-628.

https://doi.org/10.4236/health.2020.126046

Received: May 20, 2019

Accepted: June 15, 2020

Published: June 18, 2020

Copyright $\odot 2020$ by author(s) and Scientific Research Publishing Inc. This work is licensed under the Creative Commons Attribution International License (CC BY 4.0).

http://creativecommons.org/licenses/by/4.0/

\begin{abstract}
Introduction: In August 2014, the Yazidi community of Sinjar, in the Nineveh Governorate of Northern Iraq, was brutally targeted by the so-called Islamic State of Iraq and Syria (ISIS) for annihilation through murder, torture, and the systematic and premeditated use of rape and sexual slavery of Yazidi women. In 2016, the United Nations High Commissioner for Human Rights concluded that ISIS was committing genocide, crimes against humanity, and war crimes against Yazidis. Methods: Using current international literature, which includes reviews, qualitative interviews of survivors, and reports from medical and humanitarian actors, this paper explores the short and potentially long-term physical and mental health consequences of the extreme physical and sexual violence and atrocities perpetrated against Yazidi women. Results: Yazidi women survivors of kidnapping, sex slavery, and rape experienced significant levels of physical ailments, chronic pain, and mental health conditions. All women reported feelings of guilt, stress, insomnia, and severe flashbacks. The incidence of post-traumatic stress disorder (PTSD) ranged from $42 \%$ to $90 \%$. Sixty-seven percent suffered from a somatoform disorder, 53\% had depression, 39\% experienced anxiety, and 28\% suffered from dissociation. Conclusions: Sexual violence against women is a common tool systematically employed during wars and genocide. In recent ISIS attacks, intentional perpetration of mass rapes of women and execution of men was a strategy to destroy an entire population. PTSD and depression are
\end{abstract}


common after traumatic stress. For disaster responders and humanitarian workers, training and education to understand, try to prevent, and plan for interventions when gender-based violence and sexual exploitation occurs must become a mandatory part of emergency preparedness.

\section{Keywords}

Rape, Rape as a Weapon of War, Sexual Violence, Sexual Slavery, Kidnapping, ISIS, ISIL, DAESH, Yazidi, Genocide

"Our girls, our girls, confined in chains, dragging the world along behind them. Some of them fall to the ground in the water in the dirt in the air on the ground, leaving the world without meaning, like a clock with only a long hand. Who's left in the village?" (Mikhail, The Beekeeper. Rescuing The Stolen Women Of Iraq, 2018).

\section{Introduction}

In August 2014, the Yazidi community of Sinjar, in the Nineveh Governorate of Northern Iraq, was brutally targeted by the so-called Islamic State of Iraq and Syria (ISIS) for annihilation through murder, torture, and the systematic and premeditated use of rape and sexual slavery of Yazidi women [1] [2]. ISIS seized one-third of Iraq's territory causing massive displacement of its citizens, with more than 830,000 people being forced from their homes [3]. At least twenty historic sites of worship were destroyed [4]. The vast majority of Yazidis escaped to the Kurdistan region of North Iraq by late August 2014, but thousands of Yazidis were killed or kidnapped. In 2016, the United Nations High Commissioner for Human Rights concluded that ISIS was committing genocide, crimes against humanity, and war crimes against Yazidis [5].

This paper reviews the background, history, and religion of the Yazidi community who were targeted as a religious minority, and what is known about the actions of ISIS in the destruction and genocide of the Yazidi community, including an understanding of the number of Yazidi casualties of men, women, and children. The background and impact of ISIS, as terrorist actors, are summarized.

Using current international literature, which includes reviews, qualitative interviews of survivors, and reports from medical and humanitarian actors, this paper explores the short and potentially long-term physical and mental health consequences of the extreme physical and sexual violence and atrocities perpetrated against Yazidi women. Additionally, this report reviews the challenges these women face reintegrating into their surviving communities as part of the overall public health consequences of the ISIS reign of terror.

\section{Methods}

A search for peer-reviewed papers from 1990 to 2020 via the Ovid MEDLINE 
database, followed by a PubMed search to identify more recent papers not currently indexed was used. The year 1990 was used as a beginning point, which was when the Balkan Wars led to the use of mass rape as a weapon of war [6]. In this time period, mass rape and sexual torture were internationally acknowledged as instruments of genocide for the first time [7]. References for included papers were crosschecked to ensure that all relevant literature was identified and included. A combination of terms describing Rape, Sexual Violence, Sexual slavery, trauma, rape as a weapon of war, post-traumatic stress, kidnapping, ISIS, ISIL, DAESH, and Yazidi was used in the search. An Internet search was done to identify pertinent news stories and reports documenting the events of the ISIS invasion of Northern Iraq from international humanitarian aid groups such as United Nations Refugee Agency, World Health Organization, Amnesty International, Human Rights Watch.

For inclusion, papers must have focused on sexual assault in the setting of war, conflict, and terror attacks. Articles on survivors of sexual assault, outcomes and therapeutic interventions were included. Papers were excluded if not available in English. Any study design was eligible for review. A final 75 references of papers and websites were included in this review. Figure 1 shows the PRISMA flowchart.

\section{Review of the Literature}

\subsection{Yazidi Culture}

Yazidis (also spelled Yezidi and Êzîdî) are a small ethnic-religious minority who speak the Northern Kurdish language, Kurmanji, and were historically spread over several Middle Eastern countries (Iraq, Syria, Turkey, Armenia). Their total population worldwide is estimated at 800,000 to $1,000,000$ [8]. The largest Yazidi community of approximately 400,000 people lived in the area of Mount Sinjar in Northern Iraq [9]. The Yazidi religious monotheistic tradition has roots in pre-Islamic ancient Persian origin, with influences from Sufi mysticism, and contains elements of Zoroastrianism, Judaism, Christianity, and Islam. In Yazidi mythology, they are the people created by God who passed on commands to seven angels. The Peacock Angel, Melek Taus, is the chief angel. The religion is closed to outsiders and conversion is not allowed [10]. Yazidis who marry outside of the community are ostracized [8].

Religious rituals are inseparable from the cycle of nature. Several times a day, Yazidis worship God by facing towards the sun, heavens, and moon. They worship light, which is why they face the sun when they pray [11]. There are festivals of New Year (in the month of April), summer, and winter and an annual summer pilgrimage to Lalish, a temple in mountain valley in the Kurdistan region of Iraq, a mystical place and the holiest temple in their religion.

There are three hereditary Yazidi castes: Two clergy castes, Sheiks and Pirs, and the laymen Murid caste [12]. There are three general socioreligious principles for all Yazidis: Sheriet, marriage is permitted only to other Yazidis; Teriquet, 


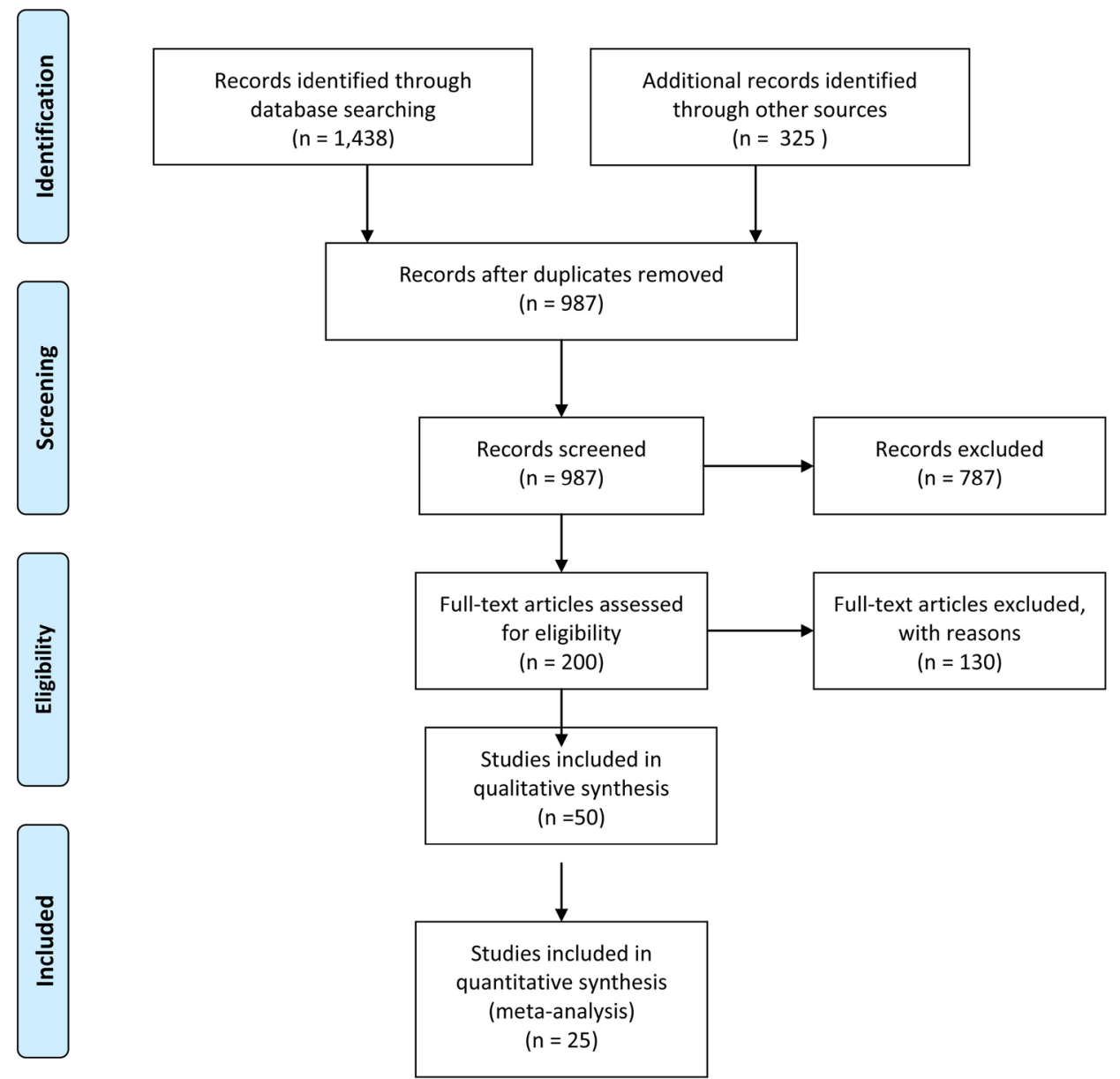

Figure 1. PRISMA 2009 flow diagram.

marriage is permitted only to members of your own caste; and Derba Kherqe Shekhadi, respect religious authority [13] [14].

It is common and highly desirable to marry a cousin [13]. The code of honor makes a bride's virginity extremely important. Women are not required to cover their heads. White is the color of spiritual purity. The Yazidis have a male-dominated and community-oriented culture [15]. Compliance with the rules of the community is considered necessary to enter paradise [16].

Historically, there has been a long history of persecution and suffering against Yazidis. They have been attacked by Muslim Kurds, the Iranian government, the Ottoman Sultans, and most recently prior to ISIS, the Sunni extremists [17]. The story of Yazidi survival in the history of its people includes the stories of the "72 persecutions" known as Fermans over the past 800 years to force Yazidis to renounce their religion [18]. In 2007, two Yazidi villages were destroyed in a large Islamist terror attack; this is known as the 73th Ferman. Their persecutors have denigrated Yazidis as "Ibadat al-Shaytan": "those who worship the Lord of Hell". ISIS called them "devil-worshippers" [19]. Their exceptionalism, minority status, and rejection of Islam made them a significant target for the ISIS terror group and led to the $74^{\text {th }}$ Ferman. 


\subsection{Terrorism and Islamic State of Iraq and Syria (ISIS)}

There are many definitions of terrorism. The United States Department of State defines Terrorism as premeditated, politically motivated violence perpetrated against non-combatant targets by sub-national groups or clandestine agents, usually intended to influence an audience [20]. Forest defines more broadly: "Terrorism is a combination of strategies and violent tactics in which the victims (e.g. ordinary citizens) are a sub-element of broader target (e.g. a government). These strategies and tactics are used by individuals or groups in pursuit of objectives, typically of a political, social, criminal, economic, and/or religious nature, and they perceive terrorism to be the most effective way to obtain the power needed to achieve those objectives" [21]. Individuals who carry out these attacks are consumed by hatred towards their victims and targets and display a willingness to kill without remorse. Genocide, defined as acts perpetrated with the intent of destroying a group based on its national, ethnic, racial, political, or religious roots, includes killing, serious mental or bodily harm, impairing the ability to procreate, expulsion, or creating impossible living conditions [22]. A final brutality of genocide is to politically silence the telling of the story so that the existence of the people annihilated disappears from the annals of history [18]. The incitement to terrorism and ultimately to genocide as accomplished by ISIS comes from inspiring individuals and groups to violent action through the " 5 D's": dehumanization, demonization, delegitimization, disinformation, and denial of past atrocities [23].

Al-Dawla al-Islamyia fil Iraq wa'al Sham (Islamic state of Iraq and Syria) (ISIS) (also called Daesh and ISIL) was led by Abu Bakr al-Baghdadi, until his death by suicide bombing in October 2019. ISIS used clandestine terrorism tactics combined with the development of a military machine to create its own version of an Islamic State. Part of the vision of ISIS was and is to annihilate all individuals and populations who do not conform to its vision [23]. The events in Northern Iraq demonstrate clearly the lethal scope of this vision.

Population-based estimates from a survey of Yazidi households in refugee camps in the Kurdistan region of Iraq documented the scale of ISIS attack against the Yazidi people living in Sinjar [9]. This research estimates that 2.5\% (approximately 9900 people) of the Yazidi population were killed or kidnapped in August 2014. Of an estimated 3100 people who were killed, half were executed and the other half, nearly all children, died from starvation, dehydration, or injuries. The estimated 6800 who were kidnapped suffered abuses including forced conversions, torture, and sex slavery. Over one third of those kidnapped were still missing at the time of the survey in 2015. It is unknown how many women may still be in captivity at this time in 2020, however, in 2017 there were estimates that 2500 - 3800 Yazidi women were still captive [9] [24] [25].

Amnesty International (AI) interviewed witnesses and survivors who reported the mass killings of Yazidi men in multiple villages in August 2014, including the mass murder of 400 men shot to death in Kocho [1]. Executions by ISIS were in- 
discriminate and included the murder of children and adults. This information has been confirmed through the discovery of thirty-five mass graves around the city of Kocho [26].

Thousands of women and girls were systematically abducted and sold as sexual slaves [11] [13] [14] [27]. In 2014, AI reported that hundreds and possibly thousands of women and girls as young as eight years old were subjected to rape and sexual abuse and forced into labor to make rockets [1] [8]. Male children were beaten and forced to study Koran, build rockets, and become child soldiers [28]. ISIS called the women "Sabaya" (sex slaves). In another report, survivors described girls as young as nine to be "married" to militants [11]. ISIS developed an organized system of kidnapping, transportation, and accommodations of enslaved Yazidi women including a register and an online auction site [29]. While ISIS is not the first terrorist group to use kidnapping and sex slavery as a terrorist tool, the scale and extent at which slavery and sexual violence is incorporated into the social and financial fabric of the organization is unprecedented [30]. The International Centre for Counter-Terrorism developed a framework to describe ISIS's systematic processing of captives, the Division and Regulation Enslavement Framework. Women and girls were separated by marital and childbearing status, and virginity carried a high value on the slave market [30].

\subsection{Public and Personal Health Consequences for Yazidi Women}

Table 1 summarizes the health disorders experienced by Yazidi women survivors. Both physical illness and profound mental health disorders have long-term and persistent consequences for these survivors of kidnapping, sex slavery, rape, and other physical and mental trauma. A recent population survey analyzed the

Table 1. Health consequences for survivors of kidnapping, sex slavery, and rape.

\begin{tabular}{ll}
\hline PHYSICAL HEALTH [8] [11] [31]-[37] & \multicolumn{1}{c}{ MENTAL HEALTH [8] [15] } \\
\hline General & \\
Hypertension & \\
Musculoskeletal Disorders & \\
Diabetes & Post-traumatic Stress Disorder (PTSD) \\
Gastrointestinal disorders & Major depression \\
Pain disorders & Psychosomatic Illnesses \\
Malnutrition & Anxiety \\
Insomnia & Dissociation \\
Dizziness & Psychosis \\
Neurocognitive disorders & Suicidality \\
Obstetric and Gynecologic Conditions & \\
Genital and Pelvic Pain & \\
Lacerations & \\
Unwanted pregnancies & \\
Sexually transmitted diseases & \\
Illegal pregnancy terminations & \\
Maternal mortality & \\
&
\end{tabular}


relationship of thirty-one specific physical conditions with ten broad categories of mental illness among non-refugee population in peacetime, and noted that most mental illnesses are associated with an increased risk of subsequent medical conditions [31]. In another study of a forty-year follow-up of women war veterans, exposure to dealing with death, sexual discrimination, harassment and consequent PTSD was associated with lower health functioning and greater disability [32]. In the setting of extreme violence, direct and lasting health consequences are even more profound. Studies referencing outcomes of violence in multiple countries have demonstrated the significantly high rates of morbidity and mortality in survivors of human rights violations [33]. In Iraq, a survey of thirteen camps run by the Kurdish Board of Relief and Humanitarian Affairs, where displaced Yazidi communities now reside, over one third of households required healthcare interventions for both communicable and non-communicable disease and for mental health problems and physical injuries [34]. Twelve and a half percent of adult women had pathologic gynecologic problems and 15\% had mental health problems, including post-traumatic stress disorder (PTSD) and major depression. Surveys report a high prevalence in sexual assault survivors of non-communicable disease such as hypertension (19.7\%), musculoskeletal conditions (13.5\%), and diabetes (9.7\%) [35]. In another investigation of internally displaced persons (IDP) camps in Northern Iraq, $62 \%$ of survivors, all less than 45 years of age, self-reported poor overall health [36]. Survivors suffer from pain all the time, which can manifest through psychosomatic illnesses [8] [11]. In interviews of 116 ISIS-traumatized women survivors, the severity of trauma-related somatic symptoms was evaluated [37]. Pain was the major somatic complaint in $73 \%$ of the women. These survivors also commonly endorsed feelings of suffocation including shortness of breath, and movement disorders such as difficulties walking and with coordination of movements.

Physical problems often develop from repeated sexual assault. Survivors of systematic rape experience significant genital injuries, and the often-resulting pregnancies are another source of shame and trauma [38]. Although there are few studies exploring the consequences of these pregnancies in the context of the Yazidi community, other work on survivors of war-related rape show that one in five women reported a sexual violence-related pregnancy (SVRP) [39]. In a mixed methods study in the Democratic Republic of Congo, psychological wellbeing of women with SVRPs was directly impacted and worsened by negative reactions from their peers and elders including stigmatization, abandonment by husbands, and social rejection [40]. In traditional Yazidi culture, the community prefers that women do not keep the children from rapes, resulting in reports of a high number of illegal abortions among surviving Yazidi women [41]. One survivor was quoted as saying, "Nobody wants to have the children of terrorists" [11]. It is known that $25 \%$ to $50 \%$ of maternal deaths are secondary to complications of illegal abortions [42]. In addition, in Iraq each civilian is required to have an identity card that includes religion as an identifier and is considered a priority factor. At birth, the child's religion is assigned based on the biological 
father's religion, which in these cases would make the child Muslim. Yazidi women are then forced to choose between abandoning their children born of rape to return to their Yazidi communities or staying with their children [30] [43].

\subsection{Mental Health}

Survivors of torture and sexual violence are at high risk for both acute and long-term mental health disorders. Risk factors for significant disorders include older age, female gender or coming from a rural background [44]. Worldwide, the prevalence of depression and PTSD among refugees is 30\% [45]. Experience of sexual violence and torture is a strong predictor of these disorders [46]. A review of twenty publications from six countries that reported on the long-term effects of war-related sexual violence identified that survivors experienced extreme rates of PTSD, depression, and anxiety [47]. In one report of Yazidi women survivors, forty-two percent experienced PTSD and another $35.9 \%$ suffered from major depression [48]. A separate study of 108 Yazidi women who had been subjected to captivity by ISIS reported a 50.9\% rate of complex PTSD and another 20\% with probable PTSD [49]. Interviews with another 416 surviving Yazidi women sheltered in IDP camps in the Kurdistan region of Iraq identified an exceptionally high PTSD rate of $90 \%$ [15]. These high rates were attributed to the insecurity of these particular camps and the isolation many women felt, deprived of their families and homeland. In another survey of 296 Yazidi women survivors living in Germany, $82 \%$ of the women had been physically tortured. Sixty-seven percent suffered from a somatoform disorder, $53 \%$ had depression, $39 \%$ experienced anxiety, and $28 \%$ suffered from dissociation [50].

Children, also, are deeply harmed by mass violence and terrorism. PTSD in children was proportional to level of exposure to violence, history of rape, and witnessing others being killed or tortured [51]. Surviving refugee children are resilient. Protective factors against long-term psychological distress include being accompanied by a parent, social support, and stable settlement. However, major depression and ongoing trauma symptoms have been reported among surviving Yazidi children in Turkish refugee camps [52].

In a case study of Yazidi survivors, all women reported feelings of guilt, stress, insomnia, and severe flashbacks, and experienced neurocognitive disorders and psychosis [53]. Other symptoms include nightmares, gastrointestinal complaints, and dizziness [54]. A specific enslavement trauma scale with 20-item events (e.g. forced conversion, being sold in ISIS sex slave markets, witnessing beheading, witnessing people being burnt to death) was developed to fully document the depth of trauma experienced by survivors [11]. Mental health symptoms directly correlated with the intensity of trauma exposure. Risk of suicide along with major depression continues to be a danger for rape survivors over their lifetime [55] [56] [57]. According to one Yazidi survivor, "Staying alive doesn't mean permanent survival. Anyway what is survival when the calamity 
survives along with you? To survive all alone is the worst kind of survival" [11].

\subsection{Consequences to Yazidi Society}

Yazidis have a strong connection to their place of origin where sanctuaries and holy shrines are localized and are extremely important for the existential meaning of their lives [8]. The displacement of Yazidis in and of itself and the complete destruction of some of their ancestral villages is an enormous rent in the fabric of the community.

Studies have well documented the social stigma and societal rejection of women after sexual slavery in other conflicts [58]. In contrast, social support and acceptance is the single most important predictor of healing from trauma [59]. In interviews with survivors of sexual slavery, perceived social rejection by their community was significantly associated with poor mental health among Yazidi women [15]. As one study explains, "very few women want to speak openly about it because they don't dare, because they are ashamed of what happened..." [24]. Violation of honor is an important negative concept in Yazidi culture and women carry the fear of exclusion from their community as a result of their trauma [8]. Some women have committed suicide because of their fear of being discriminated against by their own community [8] [36] [60] A recent study shows that six years after the start of the 2014 ISIS assault on Sinjar, the Yazidi community remains both physically and culturally fragmented, a continuing legacy of the ISIS-led genocide [61]. Refugee women in general and Yazidi women in camps are at risk for continued gender-based violence [36] [62].

The United Nations Security Council has recognized rape as a tactic of war, specifically used to "to humiliate, dominate, instill fear in, disperse and/or forcibly relocate civilian members of a community or ethnic group" [63]. What was once considered an inevitable consequence of soldier's absence of female companionship has now been redefined as an intentional terrorist method to weaken community social ties, or, as described by author Slavenka Drakulic, "a kind of slow murder" [63]. The use of sexual assault by ISIS fits the definition of a war tactic to destabilize the Yazidi community as a whole.

Yazidi Spiritual leader Baba Sheikh has worked to bring the community back together and accept rescued and escaped women. He issued a statement declaring that "Yazidi girls running away from Daesh were helpless, powerless yet brave when resisting terrorism and their honor cannot be impugned even if their hymens are damaged" [11]. In addition, he declared that Yazidis would accept children of ISIS rape into their community [64]. In 2019, the Yazidi Supreme Spiritual Council allowed the return of women residing in IDP camps who had refused to be separated from their children and has initiated searches of orphanages across Iraq for hundreds of Yazidi babies born of rape [65]. The Yazidi community has also established special rituals in its holy temple, Lalish, to rehabilitate abducted women [66].

Yazidi women affected by these acts of terrorism continue to display incredi- 
ble strength [13] [14]. The Yazidi community has historically heavily relied on women, who are responsible for parenting and for the oral transmission of cultural heritage [18] [36]. A systematic review of 217 articles on the impact of terrorist events worldwide identified the strong role of resilience, fortitude, and courage amongst those affected, and stressed the importance of families in recovery [57].

\subsection{Interventions}

Trauma-specific interventions, including short-term psychological first aid and longer-term psychiatric treatment, were part of the care given to Yazidi refugees [67] [68]. Germany accepted 1000 very physically ill and mentally traumatized Yazidi women and children for integrated care as part of a special quota project to support 2500 women and children who had been held hostage by ISIS [53]. These integrated care interventions aim to heal the trauma of humiliation and bodily invasion by giving women platforms and allowing them to tell their stories [69]. The stories of past persecutions, called "Fermans" (equivalent to the Holocaust), are part of the collective Yazidi memory. Acknowledging this shared experience in the context of recent trauma can be a mechanism to strengthen resilience in survivors [8] [18]. Of note, secondary traumatization was present in $22 \%$ of the caregivers, interpreters, physicians, psychotherapist, and social workers working with surviving Yazidi women and children [70].

Another phase of healing requires bringing justice and retribution against terrorists [71]. Identifying the actions of ISIS as war crimes and crimes against humanity is the first step in accomplishing that goal [5] [72]. Unfortunately, crimes of sexual violence and enslavement have not been considered in domestic terrorism charges in Iraq, requiring the utilization of the International Criminal Court to pursue and prosecute ISIS members [30] [73].

\section{Discussion}

Currently, the United Nations High Commissioner for Refugees (UNHCR) has identified 70.8 million forcibly displaced people, of whom 25.9 million are refugees [74]. Sexual violence against women is a common tool systematically perpetrated during wars and genocide. The purpose of mass sexual violation is to eliminate a particular group through desecration of the central core of a community, its women, mothers, and families [75] [76]. In recent ISIS attacks and in previous documented wars and conflicts in Rwanda, Democratic Republic of Congo, and Bosnia, intentional perpetration of mass rapes of women is a strategy to destroy a population [77]. In addition, the tactic of enslavement contributes to the military, financial and political growth and empowerment of ISIS [30]. The genocidal assault against the Yazidi population was gender-specific; men were executed and women were sexually violated [36] [78]. Women are at especially high risk for PTSD and depression after traumatic stress [48]. Survivors of torture and sexual slavery also struggle with deep existential issues sur- 
rounding their legitimacy and place in their community as women, mothers, and wives.

From a public health perspective and using social ecological models of health, there are several key areas that those involved in emergency preparedness response must understand and plan for: the health challenges of survivors, the concurrent and future health challenges of the next generation, and the functionality of the community at large after such devastating collective trauma. Additionally, humanitarian aid workers, public health experts, and medical providers must also ask questions specific to the particular culture and population that has been victimized, including: What are the risk factors for post-traumatic stress disorder, suicide, and potential vulnerability to domestic violence after abduction and sexual exploitation and abuse? How can we support and foster resilience and healing for women and their communities after such events?

The Sendai framework of emergency preparedness includes mitigation, preparedness, response, and recovery and focuses on habitat safety, structural safety of buildings, and physical health [79]. Training and education to understand, try to prevent, and plan for interventions when gender-based violence and sexual exploitation occur must become a mandatory part of emergency preparedness. The tactics of ISIS and the financial success of its sex slave business should teach us that future large-scale terrorist attacks may include this atrocity again and are ultimately a threat to public health and social stability.

\section{Conclusion}

Sexual violence against women is a common tool systematically employed during wars and genocide. In recent ISIS attacks, intentional perpetration of mass rapes of women and execution of men was a strategy to destroy an entire population. Yazidi women survivors of kidnapping, sex slavery, and rape and other physical and mental trauma experienced significant levels of physical ailments, chronic pain, and mental health conditions. All women reported feelings of guilt, stress, insomnia, and severe flashbacks. The incidence of post-traumatic stress disorder (PTSD) ranged from $42 \%$ to $90 \%$. Both physical illness and profound mental health disorders have long-term and persistent consequences for these survivors.

\section{Conflicts of Interest}

The authors declare no conflicts of interest regarding the publication of this paper.

\section{References}

[1] Amnesty International (2014) Ethnic Cleansing on a Historic Scale: Islamic State's Systematic Targeting of Minorities in Northern Iraq. Amnesty International Report. https://www.amnesty.org/en/documents/MDE14/011/2014/en

[2] Hasen, S.H. (2016) Investigating Sexual and Gender-Based Violence as a Weapon of War and a Tool of Genocide against Indigenous Yazidi Women and Girls by ISIS in 
Iraq.

https://ir.library.oregonstate.edu/concern/graduate thesis or dissertations/m613n1 $19 \mathrm{r}$

[3] Higel, I. (2016) Ceasefire Centre for Civilian Rights and Minority Rights Group International. Iraq's Displacement Crisis: Security and Protection. Minority Rights Group International Report.

https://minorityrights.org/wp-content/uploads/2016/04/CEASEFIRE-report ENGL ISH march-2016 210x297mm WEB.pdf

[4] Isakhan, B. and Shahab, S. (2020) The Islamic State's Destruction of Yezidi Heritage: Responses, Resilience, and Reconstruction after Genocide. Journal of Social Archaeology, 20, 3-25. https://doi.org/10.1177/1469605319884137

[5] United Nations News (2016) UN Human Rights Panel Concludes ISIL Is Committing Genocide against Yazidis.

https://news.un.org/en/story/2016/06/532312-un-human-rights-panel-concludes-isi l-committing-genocide-against-yazidis

[6] Crowe, D.M. (2013) War Crimes, Genocide, and Justice: A Global History. Palgrave MacMillan, London.

[7] Becirevic, E. (2014) Genocide on the Drina River. Yale University Press, London. https://doi.org/10.12987/yale/9780300192582.001.0001

[8] Kizilhan, J.I. and Noll-Hussong, M. (2017) Individual, Collective, and Transgenerational Traumatization in the Yazidi. BMC Medicine, 15, 198.

https://doi.org/10.1186/s12916-017-0965-7

[9] Cetorelli, V., Sasson, I., Shabila, N. and Burnham, G. (2017) Mortality and Kidnapping Estimates for the Yazidi Population in the Area of Mount Sinjar, Iraq, in August 2014: A Retrospective Household Survey. PLoS Medicine, 14, e1002297. https://doi.org/10.1371/journal.pmed.1002297

[10] Asatrian, G. and Arakelova, V. (2003) Malak Tawus: The Peacock Angel of the Yezidis. Iran and the Caucasus, 7, 1-36. https://doi.org/10.1163/157338403X00015

[11] Mikhail, D. (2018) The Beekeeper: Rescuing the Stolen Women of Iraq. New Directions, Cambridge, $240 \mathrm{p}$.

[12] Servantgroup International (2017) Yezidi Castes, Culture, and the Elephant in the Room (3). https://servantgroup.org/yezidi-castes-culture

[13] Khalaf, F. and Hoffman, A.C. (2016) The Girl Who Escaped ISIS: This Is My Story. Atria Books, Simon \& Schuster, New York, 224 p.

[14] Murad, N. (2017) The Last Girl: My Story of Captivity, and My Fight against the Islamic State (Written with Jenna Krajeski). Tim Duggan Books, New York.

[15] Ibrahim, H., Ertl, V., Catani, C., Ismail, A.A. and Neuner, F. (2018) Trauma and Perceived Social Rejection among Yazidi Women and Girls Who Survived Enslavement and Genocide. BMC Medicine, 16, 154. https://doi.org/10.1186/s12916-018-1140-5

[16] Asatrian, G. (1999) The Holy Brotherhood: The Yezidi Religious Institution of the "Brother" and the "Sister" of the "Next World". Iran and the Caucasus, 3, 79-96. https://doi.org/10.1163/157338499X00056

[17] Maisel, S. (2008) Social Change amidst Terror and Discrimination: Yezidis in the New Iraq. The Middle East Institute Policy Brief 2008; 18. https://www.files.ethz.ch/isn/90905/No 18 Social Change Amidst Terror.pdf

[18] Six-Hohenbalken, M. (2019) May I Be a Sacrifice for My Grandchildren-Transgenerational Transmission and Women's Narratives of the Yezidi Fer- 
man. Dialect Anthropolology, 43, 161-183.

https://doi.org/10.1007/s10624-018-9506-9

[19] Kikoler, N. (2015) Simon-Skjodt Center for the Prevention of Genocide. "Our Generation Is Gone.” The Islamis State's Targeting of Iraqi Minorities in Ninewa. Bearing Witness Trip Report 2015. United States Holocaust Memorial Museum, Simon-Skjodt Center for the Prevention of Genocide, Washington DC.

[20] Abrahms, M. (2008) What Terrorists Really Want. International Security, 32, 78-105. https://doi.org/10.1162/isec.2008.32.4.78

[21] Forest, J.L.F. (2019) The Terrorism Lectures: A Comprehensive Collection for Students of Terrorism, Counterterrorism, and National Security. 2nd Edition, Chapter 1, Nortia Press, Stevens Point, 8.

[22] United Nations (1948) Convention on the Prevention and Punishment of the Crime of Genocide. United Nations General Assembly Resolution 260 A (III) of 9 December 1948 .

https://www.un.org/en/genocideprevention/documents/atrocity-crimes/Doc.1 Con vention $\% 20$ on $\% 20$ the $\% 20$ Prevention $\% 20$ and $\% 20$ Punishment $\% 20$ of $\% 20$ the $\% 20$ Crime \%20of\%20Genocide.pdf

[23] Richter, E.D., Markus, D.K. and Tait, C. (2018) Incitement, Genocide, Genocidal Terror, and the Upstream Role of Indoctrination: Can Epidemiologic Models Predict and Prevent? Public Health Reviews, 39, 30. https://doi.org/10.1186/s40985-018-0106-7

[24] Staliski, S. (2017) 3,000 Women and Children Are Still in IS Captivity. https://www.deutschlandfunk.de/un-sonderbotschafterin-nadia-murad-noch-imme r-sind-3-000.886.de.html?dram:article id=382960

[25] Amnesty International (2016) Iraq: Yezidi Survivors of Horrible Abuse in IS Captivity Neglected by International Community. https://www.amnesty.org/en/latest/news/2016/10/iraq-yezidi-survivors-of-horrific-a buse-in-is-captivity-neglected-by-international-community

[26] Yazda. (2016) Mass Graves of Yazidis Killed by the Islamic State Organization or Local Affiliated on or after August 3, 2014. Yazda Documenation Project. http://genocidewatch.net/2016/06/09/a-report-from-the-yazda-documentation-proj ect-on-mass-graves-of-yazidis-killed-by-the-islamic-state-organization-or-local-affi liates-on-or-after-august-3-2014

[27] Human Rights Watch (2014) Iraq: Forced Marriage, Conversion for Yezidis: Victims, Witnesses Describe Islamic state’s Brutality to Captives. October 11, 2014. https://www.hrw.org/news/2014/10/11/iraq-forced-marriage-conversion-yezidis

[28] Hussein, R. and Omar, K. (2018) Yazidi Children Rescued from IS Getting Psychological Help. Reliefweb. January 12, 2018.

https://reliefweb.int/report/iraq/yazidi-children-rescued-getting-psychological-help

[29] Jäger, P., Rammelt, C., Ott, N. and Brand, A. (2019) Narrative Review: The (Mental) Health Consequences of the Northern Iraq Offensive of ISIS in 2014 for Female Yezidis. International Journal Environ Res Public Health, 16, 2435. https://doi.org/10.3390/ijerph16132435

[30] Al-Dayel, N. and Mumford, A. (2020) ISIS and Their Use of Slavery. ICCT International Centre for Counter-Terrorism, The Hague. https://icct.nl/publication/isis-and-their-use-of-slavery

[31] Monen, N.C., Plana-Ripoll, O., Agerbo, E., Benros, M.E., et al. (2020) Association between Mental Disorders and Subsequent Medical Conditions. New England 
Journal Medicine, 382, 1721-1731. https://doi.org/10.1056/NEJMoa1915784

[32] Smith, B.N., Spiro, A., Frayne, S.M., et al. (2020) Impact of Wartime Stress Exposures and Mental Health on Later-Life Functioning and Disability in Vietnam-Era Women Veterans: Findings From the Health of Vietnam-Era Women's Study. Psychosomatic Medicine, 82, 147-157. https://doi.org/10.1097/PSY.0000000000000762

[33] Mullany, L.C., Richards, A.K., Lee, C.I., Suwanvanichkij, V., Maung, C., Mahn, M., Beyrer, C. and Lee, T.J. (2007) Population-Based Survey Methods to Quantify Associations between Human Rights Violations and Health Outcomes among Internally Displaced Persons in Eastern Burma. Journal Epidemiology \& Community Health, 61, 908-914. https://doi.org/10.1136/jech.2006.055087

[34] Cetorelli, V., Burnham, G. and Shabila, N. (2017) Health Needs and Care Seeking Behaviours of Yazidis and Other Minority Groups Displaced by ISIS into the Kurdistan Region of Iraq. PLOS ONE, 12, e0181028.

https://doi.org/10.1371/journal.pone.0181028

[35] Cetorelli, V., Burnham, G. and Shabila, N. (2017) Prevalence of Non-Communicable Diseases and Access to Healthcare and Medications among Yazidis and Other Minority Groups Displaced by ISIS into the Kurdistan Region of Iraq. Conflict Health, 11, 4. https://doi.org/10.1186/s13031-017-0106-0

[36] Jäger, P. (2019) Stress and Health of Internally Displaced Female Yezidis in Northern Iraq. Journal of Immigrant and Minority Health, 21, 257-263. https://doi.org/10.1007/s10903-018-0754-1

[37] Rometsch, C., Denkinger, J.K., Engelhardt, M., et al. (2020) Pain, Somatic Complaints, and Subjective Concepts of Illness in Traumatized Female Refugees Who Experienced Extreme Violence by the "Islamic State" (IS). Journal of Psychosomatic Research, 130, Article ID: 109931. https://doi.org/10.1016/j.jpsychores.2020.109931

[38] Longombe, A.O., Claude, K.M. and Ruminjo, J. (2008) Fistula and Traumatic Genital Injury from Sexual Violence in a Conflict Setting in Eastern Congo: Case Studies. Reproductive Health Matters, 16, 132-141. https://doi.org/10.1016/S0968-8080(08)31350-0

[39] Johnson, K., Scott, J., Rughita, B., Kisielewski, M., Asher, J., Ong, R., et al. (2010) Association of Sexual Violence and Human Rights Violations with Physical and Mental Health in Territories of the Eastern Democratic Republic of the Congo. $J A M A$, 304, 553-562. https://doi.org/10.1001/jama.2010.1086

[40] Scott, J., Mullen, C., Rouhani, S., et al. (2017) A Qualitative Analysis of Psychosocial Outcomes among Women with Sexual Violence-Related Pregnancies in Eastern Democratic Republic of Congo. International Journal of Mental Health Systems, 11, 64. https://doi.org/10.1186/s13033-017-0171-1

[41] Graeser, J. (2018) Attitudes on Sinjari Yezidis in Iraq Regarding the Rape of Yezidi Women and the Babies Born from Rape during the ISIS Genocide. University of Nebraska Medical Center, Omaha.

[42] Schuitemaker, N.W., Gravenhorst, J.B., Van Geijn, H.P., Dekker, G.A. and Van Dongen, P.W. (1991) Maternal Mortality and Its Prevention. European Journal of Obstetrics \& Gynecology and Reproductive Biology, 42, S31-S35.

[43] Loveluck, L. and Salim, M. (2019) Yazidi Women Raped as ISIS Slaves Face Brutal Homecoming Choice: Give Up Their Child or Stay Away. Washington Post, July 30, 2019.

https://www.washingtonpost.com/world/middle east/yazidi-women-raped-as-isis-s laves-face-brutal-homecoming-choice-give-up-their-child-or-stay-away/2019/07/30 /f753c1be-a490-11e9-b7b4-95e30869bd15 story.html 
[44] Porter, M. and Haslam, N. (2005) Predisplacement and Postdisplacement Factors Associated with Mental Health of Refugees and Internally Displaced Persons: A Meta-Analysis. JAMA, 294, 602-612. https://doi.org/10.1001/jama.294.5.602

[45] Steel, Z., Chey, T., Silove, D., Marnane, C., Bryant, R.A. and van Ommeren, M. (2009) Association of Torture and Other Potentially Traumatic Events with Mental Health Outcomes among Populations Exposed to Mass Conflict and Displacement: A Systematic Review and Meta-Analysis. JAMA, 302, 537-549. https://doi.org/10.1001/jama.2009.1132

[46] Nickerson, A., Schick, M., Schnyder, U., Bryant, R.A. and Morina, N. (2017) Comorbidity of Posttraumatic Stress Disorder and Depression in Tortured, Treatment-Seeking Refugees. Journal of Trauma Stress, 30, 409-415. https://doi.org/10.1002/jts.22205

[47] Ba, I. and Bhopal, R.S. (2017) Physical, Mental, and Social Consequences in Civilians Who Have Experienced War-Related Sexual Violence: A Systematic Review (1981-2014). Public Health, 142, 121-135. https://doi.org/10.1016/j.puhe.2016.07.019

[48] Tekin, A., Karadağ, H., Süleymanoğlu, M., Tekin, M., Kayran, Y., Alpak, G., et al. (2016) Prevalence and Gender Differences in Symptomology of Posttraumatic Stress Disorder and Depression among Iraqi Yazidis Displaced into Turkey. European Journal Psychotraumatology, 7, Article ID: 28556. https://doi.org/10.3402/ejpt.v7.28556

[49] Hoffman, Y.S.G., Grossman, E.S., Shrira, A., et al. (2018) Complex PTSD and Its Correlates amongst Female Yazidi Victims of Sexual Slavery Living in Post-ISIS Camps. World Psychiatry, 17, 112-113. https://doi.org/10.1002/wps.20475

[50] Kizilhan, J.I. (2018) PTSD of Rape after IS ("Islamic State") Captivity. Archives Women's Mental Health, 21, 517-524. https://doi.org/10.1007/s00737-018-0824-3

[51] Drury, J. and Williams, R. (2012) Children and Young People Who Are Refugees, Internally Displaced Persons or Survivors or Perpetrators of War, Mass Violence and Terrorism. Current Opinion in Psychiatry, 25, 277-284. https://doi.org/10.1097/YCO.0b013e328353eea6

[52] Nasıroğlu, S. and Çeri, V. (2016) Posttraumatic Stress and Depression in Yazidi Refugees. Neuropsychiatric Disease and Treatment, 12, 2941-1248. https://doi.org/10.2147/NDT.S119506

[53] Gerdau, I., Kizilhan, J.I. and Noll-Hussong, M. (2017) Posttraumatic Stress Disorder and Related Disorders among Female Yazidi Refugees Following Islamic State of Iraq and Syria Attacks-A Case Series and Mini-Review. Frontiers in Psychiatry, 8, 282. https://doi.org/10.3389/fpsyt.2017.00282

[54] Rometsch-Ogioun, E.L., Sount, C., Denkinger, J.K., Windthorst, P., et al. (2018) Psychological Burden in Female, Iraqi Refugees Who Suffered Extreme Violence by the "Islamic State": The Perspective of Care Providers. Frontiers Psychiatry, 9, 62. https://doi.org/10.3389/fpsyt.2018.00562

[55] Bruce, S.E., Weisberg, R.B., Dolan, R.T., Machan, J.T., Kessler, K.C. and Manchester, G. (2001) Trauma and Posttraumatic Stress Disorder in Primary Care Patients. Primary Care Companion Journal Clinical Psychiatry, 3, 211-217. https://doi.org/10.4088/PCC.v03n0504

[56] Dworkin, E.R., Menon, S.V., Bystrynski, J. and Allen, N.E. (2017) Sexual Assault Victimization and Psychopathology: A Review and Meta-Analysis. Clinical Psychology Review, 56, 65-81. https://doi.org/10.1016/j.cpr.2017.06.002

[57] Durodié, B. and Wainwright, D. (2019) Terrorism and Post-Traumatic Stress Dis- 
order: A Historical Review. Lancet Psychiatry, 6, 61-71. https://doi.org/10.1016/S2215-0366(18)30335-3

[58] Albutt, K., Kelly, J., Kabanga, J. and VanRooyen, M. (20017) Stigmatisation and Rejection of Survivors of Sexual Violence in Eastern Democratic Republic of the Congo. Disasters, 41, 211-247. https://doi.org/10.1111/disa.12202

[59] Brewin, C.R., Andrews, B. and Valentine, J.D. (2000) Meta-Analysis of Risk Factors for Post-Traumatic Stress Disorder in Trauma-Exposed Adults. Journal Consult Clinical Psychology, 68, 748-766. https://doi.org/10.1037/0022-006X.68.5.748

[60] Ahmed, H. (2014) The Yezidi Exodus, Girls Raped by ISIS Jump to Their Death on Mount Shingal. Rudaw, 14-08-2018.

https://www.rudaw.net/english/kurdistan/140820142

[61] Vale, G. (2020) Liberated, Not Free: Yazidi Women after Islamic State Captivity. Small Wars \& Insurgencies, 31, 511-539. https://doi.org/10.1080/09592318.2020.1726572

[62] Pasha, F.D. (2018) Is There a Safe Haven? Experiences of Female Ezidi Refugees in Fidanlık Refugee Camp. School of Advanced Study. University of London, London. https://sas-space.sas.ac.uk/9173

[63] UNOHCHR (2020) United Nations Human Rights Office If the High Commissioner. Rape: Weapon of War. https://www.ohchr.org/en/newsevents/pages/rapeweaponwar.aspx

[64] Salim, S. (2019) Iraq: Yazidis to Accept Children of IS Rape into Community. AP News, April 26, 2019. https://apnews.com/dd5e29b2e4634988b14d655fadddc818

[65] Chulov, M. and Rasool, M. (2019) Yazidi Leaders to Allow ISIS Rape Survivors to Return with Children. The Guardian, Aril 27, 2019.

https://www.theguardian.com/world/2019/apr/27/yazidi-leaders-to-allow-isis-survi vors-to-return-with-children

[66] Omarkhali, K. (2016) Transformations in the Yezidi Tradition after ISIS Attacks. An Interview with Ilhan Kizilhan. Kurdish Studies, 4, 148-154. https://doi.org/10.33182/ks.v4i2.429

[67] Stammel, N., Knaevelsrud, C., Schock, K., Walther, L.C., Wenk-Ansohn, M. and Böttche, M. (2017) Multidisciplinary Treatment for Traumatized Refugees in a Naturalistic Setting: Symptom Courses and Predictors. European Journal Psychotraumatology, 8, Article ID: 1377552. https://doi.org/10.1080/20008198.2017.1377552

[68] Kinzie, J.D. (2016) Medical Approach to the Management of Traumatized Refugees. Journal of Psychiatric Practice, 22, 76-83. https://doi.org/10.1097/PRA.0000000000000135

[69] Gangsei, D. and Deutsch, A.C. (2007) Psychological Evaluation of Asylum Seekers as a Therapeutic Process. Torture, 17, 79-87.

[70] Denkinger, J.K., Windthorst, P., Rometsch-Ogioun, E.L., Sount, C., et al. (2018) Secondary Traumatization in Caregivers Working with Women and Children Who Suffered Extreme Violence by the "Islamic State". Front Psychiatry, 29, 234. https://doi.org/10.3389/fpsyt.2018.00234

[71] Rubin, A.J. (2020) She Faced Her ISIS Rapist in Court, Then Watched Him Sentenced to Death. New York Times, March 2, 2020.

https://www.nytimes.com/2020/03/02/world/middleeast/isis-iraq-trial.html

[72] Tompkins, T.L. (1995) Prosecuting Rape as a War Crime: Speaking the Unspeakable. Notre Dame Law Review, 70, 845-890.

[73] Human Rights Watch (2019) Human Rights Watch Submission to the Committee 
on the Elimination of All Forms of Discrimination against Women on Iraq. 74th Pre-Sessional Working Group. March 5, 2019.

https://www.hrw.org/news/2019/03/05/human-rights-watch-submission-committee -elimination-all-forms-discrimination-0

[74] UNHCR the United Nations Refugee Agency (2020) Figures at a Glance. https://www.unhcr.org/en-us/figures-at-a-glance.html

[75] Reid-Cunnigham, A.R. (2008) Rape as a Weapon of Genocide. Genocide Studies and Prevention: An International Journal, 3, 279-296. https://doi.org/10.1353/gsp.2011.0043

[76] Von Joeden-Forgey, E. (2010) The Devil in the Details: "Life Force Atrocities" and the Assault on the Family in Times of Conflict. Genocide Studies and Prevention, 5, 1-19. https://doi.org/10.1353/gsp.0.0042

[77] Amowitz, L.L., Kim, G. and Reis, C. (2004) Human Rights Abuses and Concerns about Women's Health and Human Rights in Southern Iraq. JAMA, 291, 1505-1506. https://doi.org/10.1001/jama.291.12.1471

[78] Buffon, V. and Allison, C. (2016) The Gendering of Victimhood: Western Media and the Sinjar Genocide. Kurdish Studies, 4, 176-196.

https://doi.org/10.33182/ks.v4i2.427

[79] UNDRR United Nations Office for Disaster Risk Reduction (2015) Sendai Framework for Disaster Risk Reduction 2015-2030.

https://www.undrr.org/publication/sendai-framework-disaster-risk-reduction-2015 $\underline{-2030}$ 